\title{
The role and impact methods of state on economic in transition period
}

\author{
Giorgi Kharshiladze, PhD \\ Invited Professor of Georgian National University (SEU) \\ Cell Phone (+995 555) 30-87-08
}

Residence Address: S. Janashia str. 16/18/20 Tbilisi, Republic of Georgia

E-mail g.kharshiladze2@seu.edu.ge

June 15, 2019

\begin{abstract}
In this article is discussed the transformation process and state's economic role under the transition period. This article also deals with the main objectives and goals of state regulations, the peculiarities on countries socio-economic formation and procedures of institutional transformation. Government's role in economic development is changing during the transition period. The main important issues that must be set is strictly centralized state regulations and forms that is completely new system in economic management, that should be achieved through the elimination of state's domination over the economic system, strengthening privatization process and so on. It's true that government's dominating power should be eliminated but establishing new marketing - institutional environment and market culture should be developed only under the state's active legislative, coordinative and stimulating control.

Theoretical basis of the article represents the researches of foreign scientists, economists and international organization. The methodological basis of the article is based on economic analysis, comparison, grouping methods. While preparing the article, modern experimental methods and model of macroeconomic researches, also researches and statistical data, approaches and methodology of several international organizations were widely used.
\end{abstract}

Keywords: International institutions, transition economics, economic growth, economic integration, states role, 


\section{Introduction}

The main problem of how to transform a market from centrally planned into a market economy has emerged as one of the most influential and challenging issues in modern time. Nowadays, republics from the former Soviet Union countries and nations of East and Central Europe are in a transformation process and seeks to capture claimed efficiency and advantages of market mechanisms for their economies. This is very complex question, because a rapid transition from socialism to a market economy is unprecedented phenomenon and requires a fundamental restructuration of nation's economic, political, social and legal institutions as well as its physical infrastructure.

The term "transition economy" determines the direction of reforms that are to be implemented as in developed as well as in under developing countries. The usage of the term "transition economy" is conditioned by the necessity that one concrete term should designate the socio-economic unity, going on in post-soviet countries after the government's political decision to liquidate the centralized governmental monopoly and administration of ownership and establish market relations based emerged private ownership institutions. These changes set up a transformation intended to develop market-based institutions, where we should mean economic liberalization, where prices are set by market forces than by central planning state institutes. In market economy trade barriers are removed. There exists a serious push to the privatization of state-owned enterprises and resources, state and collectively run enterprises are restructured as a business. On the other hand, financial sector is created to facilitate macroeconomic stabilization and free movement of capital.

There are no historical precedents of transformation of centralized, planned economy into market economy like in former Soviet Union and Eastern European countries. Decentralization of economic management and planning system, faulty administrative system operating for decades, inflexible and low efficient economic mechanisms, disregard of national interests, that was due during the soviet epoch, and the attempt to carry out irrational, mutually exclusive reforms, drew soviet economics and finances to a verge.

1985-1990 revealed the tendency of slowing down national economy development: aggravated social sphere problems, worsened cultural and materialistic welfare, and decreased 
indicators of public production efficiency. Together with economic life and traditional economic links broke down significantly, low production economic crisis intensified, domestic industry and inter-industrial disproportion grow increased, and finally slow economic and social development established. Somewhere around 1990s it was obvious that within given system it was impossible to improve economics. Socialistic directive planning prevented economic development. Center was no abler to control the processes in former USSR so it became vitally important to transform established political system and abandon planned economy.

The countries under transition are striving to hurry the process of their economic, technical, technological, management development, material and cultural values by using the experience of leading countries. Development of new socio-economic system is a hard and prolonged process. It is affected by political, economic and social, technical and ecological development and particularly by the specifics of the country itself. Besides it should reflect the ways out of crisis, the stages of economic stability and the objectives of the development. Among the tendencies functioning within transition economy we can single out the following: the regulating tendencies of economic processes, that should be accomplished by government's economic policy; the new technical-technological trends of economic development, which are not able to provide new sources of economic growth and formation of modern economic structure; confirmation of the necessity of establishing market relations for effective distribution of resources; striving to open market economy, which, coming out of the objectives of efficient economic growth determines the borders of economic openness; tendency towards formation of progressive society.

There is no unified package of reforms that would be suitable for all countries under transition, because their conditions differ. Moreover, there is a disagreement about what types of reforms should be undertaken by each country. Furthermore, it has recently become evident that the most important is to determine the key elements of reform. While working on the economic reform program government firstly should concentrate on fostering the growth of social welfare; guarantee the progress to socially unsecured, especially in such circumstances when prices increase and severe monetary and fiscal policy that lead to unemployment. In transition economies it's essential to create and put into operation new institutes, systems and laws: laws which determine the private ownership rights, regulate contracts/ agreements, corporateorganizational and bankruptcy procedures; tax paying systems, which are based on strictly 
defined rules and regulations; other systems, especially those, which strictly determine the obligations and rights of accounting; information systems (accounting, audit the system of national accounts).

In order to improve the ability of potential growth, the countries of planned economy bravely headed towards market economy, which requires a set of fundamental changes and development of new types of production relations. They should by all means empty the lifeless resources accumulated in earlier economic practice; at the early stage of transition significant fall of production is observable but it's important to guarantee the economic growth in order not to make transition period either too harmful or too long; otherwise the willingness to support the economic reforms may decline and even disappear at all, which is the key factor in the process of providing successful economic transformation.

\section{Main elements and process of transition}

Property rights are considered the most basic element of the market economy. The implementation of these right is the key indicator of the transition process. Other "ingredients" of the transition process are the following:

- Liberalization - the process of allowing prices to be determined by free markets, lowering trade barriers that shut off contact with the price structure of the world's market economies;

- Macroeconomic stabilization - bringing inflation under control and lowering it over time, after the initial burst of high inflation that follows from liberalization and the release of pent-up demand. This process requires discipline over the government budget and the growth of money and credit and progress toward sustainable balance of payments ${ }^{1}$.

- Restructuring and privatization - the creation a viable financial sector and reforming the enterprises in these economies to render them capable of producing goods that could be sold in free markets and transferring their ownership into private hands;

\footnotetext{
${ }^{1}$ Aristovnik, Aleksander (19 July, 2006) - "The determinants \& Excessiveness of current account deficits in Eastern Europe and the Former Soviet Union." William Davidson Institute, University of Michigan
} 
- Legal and institutional reforms - redefining the role of the state in these economies establishing the rule of law, introducing competition policies ${ }^{2}$.

Transition process in broad sense implies liberalizing economic activity, prices, and market operations, along with reallocating resources to their most efficient use, developing indirect, market-oriented instruments for macroeconomic stabilization, achieving effective enterprise management and economic efficiency, usually through privatization; imposing hard budget constraints, which provide incentives to improve efficiency and establishing an institutional and legal framework to secure property rights, the rule of law, and transparent market-entry regulations ${ }^{3}$.

The European Bank for Reconstruction and Development (EBRD) developed a set of indicators to measure the progress in transition. The classification system was originally created in the EBRD's 1994 Transition Report, but has been refined and amended in subsequent reports. The EBRD's overall transition indicators are: large-scale privatization, small-scale privatization, governance and enterprise restructuring, price liberalization, trade and foreign exchange system, competition policy, banking reform and interest rate liberalization, securities markets and nonbank financial institutions, infrastructure reforms ${ }^{4}$.

There exist several strategies that nations adopted in transition process. The most influential was adopted by Poland launched in January 1990. This strategy was strongly influenced by IMF and World Bank. These two powerful international financial organizations analyzed those successful and unsuccessful stabilization programs which had been adopted in Latin American countries in 1980s. This strategy included a number of measures such as macroeconomic stabilization, liberalization of wholesale and retail prices, removal of constraints to the development of private enterprises and the privatization of state-owned enterprises, elimination of subsidies and the imposition of hard budget constraints, creation of export oriented economy that was open to foreign trade and investment. The creation of a social safety

\footnotetext{
2 "Transition Economies: An IMF Perspective and Progress and Prospects". IMF. 3 November 2000.

${ }^{3}$ Havrylyshyn, Oleh; Wolf, Thomas. "Determinants of Growth in Transition Countries, Finance \& Development Magazine, June 1999, Volume 36, Number 2 by the International Monetary Fund

${ }^{4}$ EBRD's 1994 Transition Report pg. 11
} 
net targeted at the individual to compensate for the removal of job security and the removal of price controls on staple goods was also part of the strategy ${ }^{5}$.

The choice between these strategies was influenced by many post-socialist critical states. Policy makes from these states were persuaded that political credibility took precedence over a sequenced reform plans and to introduce macroeconomic stabilization measures ahead of structural measures that would by their nature take longer to implement. This credibility was enhanced by the adoption of the Washington Consensus favored by IMF and World Bank. Stabilization was deemed a necessity in Hungary and Poland where state budget deficits had grown rapidly and foreign debts had become larger than the country's capacity to service. Several experts introduced stabilization programme, known as shock therapy, whose aim was to achieve external and internal balance. It was argued that "one can't jump over a chasm in two leaps." 6

Many foreign advisors were often under contract to the International financial institutions and bilateral or multilateral technical assistance programmes. These advisors favoured free trade and exchange rate convertibility rather than protection and capital controls. They supported aggressive privatization without restructuration. Exception was found in East Germany were the "Treuhand" (Trust Agency) prepared state owned enterprises at a considerable cost to the government $^{7}$. By that time several programmes had been established under European Union, such as Phare and Tacis. Other donors, including USAID, UK Know-how fund, UNDP and by the IMF, the World Bank, EBRD and KfW, which also advanced loans for stabilization, structural adjustment, industrial restructuring and social protection.

Technical assistance was delivered through the exchange of civil servants and by management consultants, including Agriconsulting, Atos, COWI, Ernst \& Young, GOPA, GTZ, Human Dynamics, Idom, IMC Consulting, Louis Berger, NIRAS, PA Consulting, PE International, Pohl Consulting, PwC, and SOFRECO.

There had been an expectation that during the introduction of current account convertibility and foreign trade liberalization would force a currency devaluation that would

\footnotetext{
${ }^{5}$ Alan Smith, Introduction in Alan Smith (editor), Challenges for Russian Economic Reform, 1995, London: Royal Institute for International Affairs and Washington DC: The Brookings Institution, p. 5.

${ }^{6}$ Marie Lavigne, The Economies of Transition: From socialist economy to market economy, 1995, London: Macmillan, pp. 117-119, 121

${ }^{7}$ Michael Kaser on Privatization in the CIS in Alan Smith (editor), Challenges for Russian Economic Reform, 1995, London: Royal Institute for International Affairs and Washington DC: The Brookings Institution, pp. 122-123.
} 
support export-led growth. ${ }^{8}$ When the prices were de-controlled enterprises and retailers raised prices, whose main aim was to match those prevailing in the black markets, or toward world price levels. On the opposite, to these price changes, consumers reduced their purchases and substituted of buying better quality imported goods that were in place of domestically produced goods. This resulted falling sales that led to the collapse of many enterprises, with personal layoffs or reduced hours of work and pay. Such situation further reduced effective demand. As imports grew and exporters failed to respond to opportunities in world markets due to the poor quality of their products and lack of resources for investment, the trade deficit expanded, putting downward pressure on the exchange rate. Many wholesalers and retailers marked prices according to their dollar values and the falling exchange rate fed inflation. The central banks in several countries raised interest rates and tightened credit conditions, depriving state agencies and enterprises of working capital. These in turn found it impossible to pay wages on time, dampening effective demand further'.

Economic situation in those countries where economies were in transition process declined much more than it was expected. The decline in output lasted until 1992-96 for all transition economies. By 1994, economic output had declined across all transition economies by 41\% compared to its 1989 level. The Central and Eastern European economies began growing again around 1993, with Poland, which had begun its transition programme earliest emerging from recession in 1992. The Baltic States came out of recession in 1994 and the rest of the former Soviet Union around 1996. Inflation remained above 20\% a year (except in the Czech Republic and Hungary) until the mid-1990s. Across all transition economies the peak annual inflation rate was 2632 percent (4645 percent in the CIS $)^{10}$. Unemployment increased and wages fell in real terms, although in Russia and other CIS economies the rate of unemployment recorded at employment exchanges remained low. Labor force surveys undertaken by the International Labor Organization showed significantly higher rates of joblessness and there was

\footnotetext{
${ }^{8}$ Marie Lavigne, The Economies of Transition: From socialist economy to market economy, 1995, London: Macmillan, pp. 130-135,

9 Marie Lavigne, The Economies of Transition: From socialist economy to market economy, 1995, London: Macmillan, pp. 130-135,

${ }^{10}$ IMF staff estimates in Stanley Fischer, Ratna Sahay and Carlos Vegh, Stabilization and growth in transition economies: The early experience, April 1996, IMF Working Paper WP/96/31, Table 2, p. 8; UNDP, Human Development Report for Central and Eastern Europe and the CIS, 1999, New York: United Nations Development Programme, Table 2.1, p. 14
} 
considerable internal migration ${ }^{11}$. High interest rates induced a "credit crunch" and fueled interenterprise indebtedness and hampered the expansion of small and medium-sized enterprises, which often lacked the connections to obtain finance legitimately ${ }^{12}$.

Several economists argued that growth performance in transition economies stemmed from the low level of development, decades of trade isolation and distortion in the socialist planed economies. They emphasized that transition strategies adopted reflected the need to resolve economic crisis besetting the socialist planed economies and the overriding objective was the transformation to market economies rather than the fostering of economic growth and welfare ${ }^{13}$.

In 2000 the EBRD reports states that the effects of the initial starting points in each transition economy on the reform process had faded. The foundations had been laid for a functioning market economy through sustained liberalization, privatization, openness to international trade and investment and the establishment of democratic political systems there remained institutional challenges. Liberalized markets were not necessarily competitive and political freedom had not prevented powerful private interests from exercising undue influence ${ }^{14}$.

Ten years later in 2010 Transition report EBRD was still finding that the quality of market enabling institutions continued to fall short of what was necessary for well-functioning market economies. Growth in the transition economies had been driven by trade integration into the world economy. But such growth had proved volatile and EBRD considered that governments in the transition economies should foster the development of domestic capital markets and improve the business environment, including financial institutions, real estate markets, transport and communications infrastructure. The EBRD expressed concerns about regulatory independence and enforcement, price setting, and the market power of incumbent infrastructure operators ${ }^{15}$.

\footnotetext{
11 Simon Clarke (editor), Structural Adjustment without Mass Unemployment? Lessons from Russia, 1998, Cheltenham: Edward Elgar, pp. 40-41, 49, 53; J L Porket, Unemployment in Capitalist, Communist and PostCommunist Economies, 1995, London: Macmillan pp. 98-100, 117

${ }^{12}$ Marie Lavigne, The Economies of Transition: From socialist economy to market economy, 1995, London: Macmillan, pp. 130, 146, 150-154

13 László Csaba, Transformation as a subject of economic theory in Zbyněk Balandrán and Vít Havránek, Atlas of Transformation, 201, Jeffrey Sachs, What I did in Russia, posted 14 March 2012;

${ }^{14}$ EBRD, Transition Report 2000, London: European Bank for Reconstruction and Development, p. 13

${ }^{15}$ EBRD, Transition Report 2010, London: European Bank for Reconstruction and Development, pp. 2-5
} 
Income inequality, which can be measured by Gini coefficient, rose significantly in transition economies in 1987-1988 and the mid-1990s. With income inequality, there existed poverty re-emergence between $20 \%-50 \%$ of people living below the national poverty line in the transition economies. The United Nations Development Programme calculated that overall poverty in Eastern Europe and the CIS, which increased from 4\% of the population in 1988 to $32 \%$ by 1994 or from 14 million people to 119 million $^{16}$. Unemployment and rates of economic inactivity were still high in the late 1990 according to survey data ${ }^{17}$.

The year before the global financial crisis, the index of GDP had reached 112 compared to 100 in 1989 for the transition economies. In other words, it took nearly 20 years to restore the level of output that had existed prior to transition. The index of economic output (GDP) in the countries of Central and Eastern Europe was 151 in 2007, for Balkans and South=Eastern Europe the index was 111 and for the Commonwealth of Independent States and Mongolia it was 102. Several CIS countries in the Caucasus and Central Asia, as well as Moldova and Ukraine had economies that were substantially smaller than in $1989^{18}$.

Global financial (2008-2009) and Eurozone crisis (2011-2013) destabilized the transition economies, reduced growth rate and increased unemployment. Such slowdowns hit government revenues and widened fiscal deficits, but almost all transition economies had experienced a partial recovery and had maintained low and stable inflation since $2012^{19}$.

Transition trajectories have varied considerably in practice. Several nations have been experimenting with market reform for several decades, while other are relatively recent adopters. In some cases, reforms have been accompanied with political upheaval such as the overthrow of a dictator, the collapse of government, a declaration of independence, or integration with another country. In other cases, economic reforms have been adopted by incumbent government with little interest in political change.

Transition trajectories have varied considerably in practice. Some nations have been experimenting with market reform for several decades, while others are relatively recent adopters (e.g., Macedonia, Serbia, Montenegro) and Albania. In some cases, reforms have been

\footnotetext{
16 The UNDP used a poverty line of \$4 per person per day in 1990 dollars at purchasing power parity; UNDP, Human Development Report for Central and Eastern Europe and the CIS, 1999, New York: United Nations Development Programme, Table 2.5, pp. 20-21

${ }^{17}$ EBRD, Transition Report 2000, London: European Bank for Reconstruction and Development, Table 5.2, p. 103

${ }^{18}$ EBRD, Transition Report 2008, London: European Bank for Reconstruction and Development, Table A.1.1.1, p. 13

${ }^{19}$ EBRD, Transition Report 2013, London: European Bank for Reconstruction and Development, pp. 8 and 99-105.
} 
accompanied with political upheaval, such as the overthrow of a dictator (Romania), the collapse of a government (the Soviet Union), a declaration of independence (Croatia), or integration with another country (East Germany. In other cases economic reforms have been adopted by incumbent governments with little interest in political change (China, Laos, Vietnam) ${ }^{20}$ Transition trajectories also differ in terms of the extent of central planning being relinquished (e.g., high centralized coordination among the CIS states) as well as the scope of liberalization efforts being undertaken (e.g., relatively limited In Romania). Some countries, such as Vietnam, have experienced macro-economic upheavals over different periods of transition, even transition turmoil. $^{21}$

According to the World Bank's 10 Years of Transition report "... the wide dispersion in the productivity of labor and capital across types of enterprises at the onset of transition and the erosion of those differences between old and new sectors during the reform provide a natural definition of the end of transition." ${ }^{22}$ According to the EBRD a well-functioning market economy should enjoy a diverse range of economic activities, equality of opportunity and convergence of incomes. These outcomes had not yet been achieved by 2013 and progress in establishing well-functioning market economies had stalled since the 1990s. On the EBRD's measure of transition indicators the transition economies had become "stuck in transition". Price liberalization, small-scale privatization and the opening-up of trade and foreign exchange markets were mostly complete by the end of the 1990s. However economic reform had slowed in areas such governance, enterprise restructuring and competition policy, which remained substantially below the standard of other developed market economies ${ }^{23}$.

Inequality of opportunity was higher in the transition economies of Central and Eastern Europe and Central Asia than in some other developed economies in Western Europe (except France, where inequality of opportunity was relatively high). The highest inequality of opportunity was found in the Balkans and Central Asia. In terms of legal regulations and access to education and health services, inequality of opportunity related to gender was low in Europe

\footnotetext{
${ }^{20}$ Vuong, Quan-Hoang. (2010). Financial Markets in Vietnam's Transition Economy: Facts, insights, implication. Saarbrücken, Germany: VDM Verlag (Feb. 2010)

${ }^{21}$ Napier Nancy K, Vuong Quan Hoang. (2013). What we see, why we worry, why we hope: Vietnam going forward. Boise, ID: Boise State University CCI Press, October 2013

${ }^{22}$ The first ten years: Analysis and Lessons for Eastern Europe and the Former Soviet Union" (PDF). The International Bank for Reconstruction and Development/The World Bank 2002 pp. xix, xxxi.

${ }^{23}$ EBRD, Transition Report 2013, 2013, London: European Bank for Reconstruction and Development, pp. 8 and 13
} 
and Central Asia but medium to high in respect of labor practices, employment and entrepreneurship and in access to finance. In Central Asia women also experienced significant lack of access to health services, as was the case in Arab countries ${ }^{24}$. While many transition economies performed well with respect to primary and secondary education, and matched that available in many other developed economies, they were weaker when it came to training and tertiary education ${ }^{25}$.

Over the decade 1994 to 2004, the transition economies had closed some of the gap in income per person with the average for the European Union in purchasing power parity terms. These gains had been driven by sustained growth in productivity as obsolete capital stock was scrapped and production shifted to take advantage of the opening-up of foreign trade, price liberalization and foreign direct investment. However the rapid growth rates of that period of catch-up had stalled since the late 2000s and the prospects for income convergence have receded according to the EBRD's prognosis, unless there are additional productivity-enhancing structural reforms ${ }^{26}$.

To Spur further economic reform and break out of various circle, the EBRD Transition report 2013 proposed that the transition economies should: open trade and finance, which made reform more resilient to popular pressures ("market aversion") and meant that countries could access the EU single market either as member states or through association agreements (such as those being negotiated with Ukraine, Moldova and Georgia); Encourage transparent and accountable government, with media and civil society scrutiny, and political competition at elections; Invest in human capital, especially by improving the quality of tertiary education ${ }^{27}$.

\section{The role of state in process of transformation of national economies}

An active state role in the economy does not itself guarantee economic success, in development or in transition. The wrong active state policies can fail to achieve goal. A state can become an institution that is parasitic on society and obstructs economic progress. However, when the state just stands aside, waiting for individual action and non-state forces such as

\footnotetext{
${ }^{24}$ Ibid: pp. 6, 78-96.

${ }^{25}$ Ibid: p. 6.

${ }^{26}$ EBRD, Transition Report 2013, 2013, London: European Bank for Reconstruction and Development, pp. 4, 8, 10 17.

${ }^{27}$ Ibid pp. 5, 34, 38, 52-53.
} 
entrepreneurship, comparative advantage, and cross-border capital inflows to bring development or transition, the result is bound to be failure. The extent of that failure is potentially even greater for transition than for development. For development, the failure tends to produce stagnation, with the country locked into its unfavorable position in the world economy. For transition the consequence of fully adhering to the neoliberal strategy can be rapid movement backward, with economic and social collapse in the worst case.

The state is the only institution in society that is in a position to guide a transition from central planning to a market economy. Unlike individuals, the state can formulate the goal of transforming the economic system and then undertake the steps necessary to accomplish that transformation. To do so it must create conditions that channel the profit motive of individuals into productive ends. The appropriate state role includes, at the least, the following: assuring that adequate, low-cost financing is available for market-oriented productive activity; assuring growing aggregate demand; investing in necessary infrastructure for the new patterns of production and trade that will develop in a market economy; protecting domestic industries from superior foreign competition at least for a certain period of time

To the well-functioning of market economies, governments needs to perform their optimal function that in turn can establish and enforce the rules of games, promote social objectives, raising revenues to finance public sector activities, spend revenues productively, enforce contracts and protect property, and produce public goods. They also need a pared-down set of regulations that are clear and leave little margin for interpretation or discretion. While the guiding principle under central planning was that nothing was permitted unless explicitly authorized, the guiding principle in a market economy should be that everything is permitted unless expressly forbidden. State's role in this process is very important, because they can play a huge role in the development of social, financial, macroeconomic stabilization, foreign trade policy spheres.

An effective government in fact is a precondition of transition to market economy. There exist three main reason of this. First, voluntary transactions can't take place in an institutional vacuum. The well-known fact about market economy is that, it can't exist without legal, administrative, regulatory and attractive institutions maintained by state. Institutions are needed to conduct the following functions: enact a system of laws, enforce contracts, collect taxes, oversee banks, supervise corporate entities, promote and preserve competitions, supply 
entrepreneurs with information that reduces uncertainty, cuts transaction costs and secure private sector confidence in decision making process on investment opportunities.

Second, market institutions can't spring up automatically. There exists belief that market institutions would spontaneously emerge from voluntary transactions between economic agents if the state stands aside. This has never happened before and we have no reason to believe that it is going to happen now. Market institutions, in a sense, represent the essential, irreducible minimum of "public goods" that must be provided if markets are going to work at all ${ }^{28}$. Since they are public goods, people are unlikely to cooperate voluntarily with one another to provide them, just as they would not in regard with the provision of other kinds of public goods. Of course, if the state does not provide market institutions, private economic agents would have to develop some informal rules to stem uncertainty and introduce some level of predictability into commercial transactions. In the absence of state intervention, however, these agreements are likely to evolve into pacts that neglect the interests of consumers and small producers and reflect only the preferences of those who possess economic power. Thus, as "public goods," market institutions initially have to be brought about by non-economic forces.

Third, the market transition is not a consensual but a conflictual process. The market economy is not just embedded in state institutions, it also has its ideological and moral basis, which is what the economy in the transition is lacking. Neoclassic economists' trans historic assumption about the human motivation may enable them to generate sophisticated models, but the simple fact is, as Leiberstein points out, people's behavior has often been influenced by "habits, conventions, work ethics, partial calculation, and inertia"29. When a great institutional change occurs, they often find it hard to adapt. In the case of market transition, people would not accept market values and behave according to market rules simply because the government has announced that their country has adopted the model of market economy. It took a long time for European countries to develop attitudes favorable to the formation of market systems in the eighteenth and nineteenth centuries, because, violating the "moral economy" that had preexisted

\footnotetext{
${ }^{28}$ Garnaut, Ross. 1991. "The Market and the State in Economic Development: Applications to the International Trading System," The Singapore Economic Review, vol. 26, no. 2.

${ }^{29}$ Arndt, Heinz W. 1988. "'Market Failure' and Underdevelopment." World Development, vol. 16, no. 2
} 
the market economy, practices most consistent with market rationality caused a great deal of confusion and disturbance in those societies ${ }^{30}$.

In transition economies essential part is the creation new institutions, systems and laws:

- Laws which determine the private ownership rights, regulate contracts/agreements, corporate- organizational and bankruptcy procedures;

- Tax paying systems, which are based on strictly defined rules and regulations

- Other systems, especially those, which strictly determine the obligations and rights of accounting.

- Information Systems (accounting, audit the system of national accounts);

States economic role and position is may radically change during the transition phase. Because it's important to set up strictly centralized state regulation and form completely new system of economic management. This can be achieved only thorough the elimination of state's domination over the economic system, strengthening privatization processes, fostering competitive relations, creating new marketing - institutional environment, harmonizing interests. It's true that government's dominating power should be eliminated but establishing new marketing - institutional environment and market culture should be developed only under the state's active legislative, coordinative and stimulating control.

In order to assess states' economic role, it's important to consider its involvement in economics, its regulating degree, it efficiency, optimization of state's role, how it responds to historical challenges and needs for development. For determining the efficiency of state regulation first of all it's important to check the correspondence of the acquired results with set goals and the expenses needed for it. (It's important to reduce them). Yet government is the only subject of the society in modern world, which can coordinate the transformation of the state. Its participation and influence of economic processes is crucially important.

The basic objective of state's participation in national economic administration is the realization of economic potential and initiation of favorable conditions and institutions for the development of new system. The process of selection and approbation of indirect regulation mechanisms is under way during transformation period. At the starting stage they are not as important; their importance only increases in the course of development of market relations.

\footnotetext{
${ }^{30}$ Thompson, E. P. 1971. "The Moral Economy of the English Crowd in the Eighteenth Century," Past and Present, no. 50 .
} 
Later when the methods of indirect regulation achieve their results and become sufficiently stable, they have a preference in comparison with the direct methods, as they don't contradict the basic regulator, - market mechanism but supplement and enrich it.

The structural and institutional transformation of the economy is a long process. If it is well organized and purposeful then it's the unity of concrete, coordinative events initiated by the state. Implementation of institutional reforms implies creating market institutions on every level of national economy. The institutes at macro level have more significance as they control the internal market and the whole system itself. The institute of private ownership is most important, because they regulate the independence of making economic decisions of subjects operating on market, their liabilities and obligations, stimulation of reduction of expenses and rational utilization of resources. The practice of economic transformation in transition countries has proved that the absence of institutional component increases informational indefiniteness, raises the risk of fail during exchange processes and signing contracts. All these increase economic, social and transactional expenditures of goods and services. Market cannot operate without institutional environment. The basics of building and developing modern institutions lies in the correlation of contracts and agreements, that cuts down the informational indefiniteness and risk rate, provides firm guarantees and decreases transactional expenses.

In transition period, state has several responsibilities for achieving sustainable economic growth. State authorities have to pay attention on macroeconomic stability, financial budgeting, taxing and monetary systems. Also, important roles play developing international trade relations with developed nations and reducing social risks.

One of the main problem that arises in transition period is the macroeconomic instability, which is an ordinary event. During transition phase any country's peculiarity is: its global instability. This determines the macroeconomic problem, which should be solved during transition - this is structural- investment transformation on technical- technological bases. Urgent solving of this particular issue determines the objectives at the macro levels of economic transformation that faces the country and its institutions. Macroeconomic instability, which has many different forms, has emerged as a result of combination of past and present reforms, of their objective and subjective influences.

The preliminary conditions of countries under transition can significantly vary. The difference can be in the degree of macroeconomic instability. The instability can be revealed in 
budget and foreign trade deficit, foreign debt, limited currency reserves; considerable loses in banking system and state enterprises.

Stabilization policy solves the problems that need an immediate action, such as inflation, unemployment, instability of state budget, where monetary and fiscal policy is used. The structural adaptation is concerned with the issues of long -term economic growth, namely disorder in production economy, control of prices, interest rates and exchange rate, tough customs tariffs and

quotas, introduction of taxes and subsidies. The coincidence of the implementation of abovementioned activities is crucially important for transition economy.

Short-term stabilization policy should be supplemented with the structural reforms in the spheres of budgeting and finances, monetary -fiscal and foreign economic affairs, as well as systemic reforms in ownership relations, enterprises, prices and labor market. Long term perspectives of stabilization can be provided only in case there are indirect mechanisms of macroeconomic control.

State can achieve macroeconomic stability in transition period with correct transformation of financial budgeting, taxing and monetary systems. Monetary, budgetary and price policy issues are of vital importance for transition economies, because they're in time realization can determine rapid economic development, minimization of inflation, decrease of unemployment, and settlement of the social problems in the country. According to the abovesaid, during the formation process of market economy it's crucial to work out new approach to state financial system's key entity -budget, balance budget receipts and outlays, identify the real deficit limits, improve taxing system, enhance enterprises, monetary policy regulation and management issues.

For socio-economic development of the country, structural transformation of economics and speedy stabilization processes it's significant to cleverly analyze the basics of budget formation, income sources and channels, mechanisms of their creation and utilization, rational involvement of country's leading political and economic potential.

The hardest objective of transition economy budgeting is the stabilization, which is so essential for unhampered reforms, by means of strengthening the set of budgetary policy instruments. Budget should serve as an impetus to the revival of economics, especially private sector growth and influence the advance of economic and administrative infrastructure. Because 
it's practically impossible at the first stage of transition to completely transform the activity of budget authorities and especially of tax system and budget planning, the formation of budgetary policy should be taken into account. Moreover, the structural transformation of budget should be done step by step, so that not to impede state revenue receipts and maintain their key functions. It's important to work out temporary instruments for short-term budgetary policy in order to achieve economic stabilization, gain time and later make desirable changes in instruments, which will remain long-term.

Structural transformations set forth the issues of social justice that should by all means be considered at early stages of transition period. Besides, in countries where sensitivity towards social justice and harmony is high, special taxation measures should be exercised for the achievement of consensus and successful implementation of reforms.

The abandonment of centralized control by market economy raises the necessity of new approach towards budgetary policy. Certain steps can be taken immediately in frames of tax policy. Firstly, for the rapid growth of private sector tax reform should exempt them from discriminatory taxes, which will be substituted by imposing penalties. Of great importance is also to cut down the taxes according to the categories, not to make any special benefits to anyone, and introduce equal rules for all of them. Also it's crucially important at an early stage of transition, which is accompanied by high level of inflation to take security measures for budget receipts. At an early stage, budget should be used as the key instrument for economic stabilization as: to reduce liquid funds, at least to prevent their additional growth and provide necessary resources for the recovery of different economic sectors.

The structure of tax managing authorities should change to facilitate the accomplishment of tasks, which involve new procedures of sanctions. Several years are needed for structural modifications, as far as it requires overall reorganization, selection and retraining of appropriate staff. For strengthening tax authorities it's essential to take decisive steps. It's important to create more effective controlling system to fill the gap, which remains after the modification of central planning. It's also important to set up the adequate system for stimulating government officials. It's likely that initial adjustment of prices will lead to significant decrease in salary. Under such conditions in order to reduce corruption and stimulate tax collectors it's important to use such special mechanisms as paying premiums in accordance with the tax amounts collected by them. 
Budget authorities should work out special mechanisms for balancing budget outlays and not rely on planned decisions. As far as this will need certain amount of time, which will make possible irrational utilization of resources, at an initial stage it's important to toughen control on expenses and their records. Since bureaucratic elements have different opinion about their responsibilities, its' possible to create chaos, that can negatively affect budget expenditure policy in such significant spheres as exploitation, service and social security. Reorganization of the existing systems of social maintenance and social assistance, creating new facilities for the population and development of their professional skills, reactivation of social security system are needed against probable constraints. Envisaged budget constraints and market principles for determining salary should define the distribution of maintenance in favor of socially unsecured. This will encourage the reorganization of existing administrative mechanisms, which will be oriented on distributing assistance.

While shifting to market economy it's important to transform institutional practice of deficit

financing and cash management. As far as cash inflows are not automatically sterilized, budget cannot be financed by means of money emission with the help of savings. Such a strict budget constraint forces official bodies to change work practice. Because the difference between deposit rate and loan rate is significant and government is obliged to pay much more on its own loans, the

practice of keeping big amounts on bank accounts, by those bodies that owe much to banks, will become inefficient. Efficient capital management is necessary for reducing expenditures. Moreover, it's important to eliminate the practice of accumulated unsettled debts by different public enterprises and organizations.

At an early stage of transformation, the structure and amount of budget outlays are not formed according to the demands of country, but according to the financial position of the country. As a result, budget should be drawn up socially oriented. One of the concerns of budgetary policy is to clarify the priority of financing expenses from the budget. Obviously state cannot finance equally every sphere of socio- economic activity. Thus the priorities of financing expenses should be defined and proved, which the state will undertake for a certain time. Preference should be given to such fields as economics, state investments, defense, the social 
infrastructure, education and science. Furthermore, expenses of legislative and executive bodies should be cut down.

Main direction of budgetary policy is the reduction of budget deficit by rational organization of budget receipts and outlays. Thus among budget activities the most important is working out the deficit financing system. In order to overcome budget deficit, state should take care of constantly growth of finances by improving economics, expanding production and raising efficiency. Budget deficiency shouldn't be financed by banks, because it can result in the development of inflation and negatively affect investment processes.

Government can also issue securities (bonds, short-term obligations, treasuries, etc.,) and distribute them among banks, enterprises and society, intended for the growth of budget receipts. While shifting to market economy it's important to transform institutional practice of deficit financing and cash management. As far cash inflows are not automatically sterilized, budget cannot be financed by means of money emission. Such a strict budget constraint forces official bodies to change their work practice.

For effective solving of state financial and monetary policy, it's strategic and tactical objectives, of greatest importance is the management and regulation of state debt. As a result of this successful mechanisms of managing domestic and foreign debts should be established and put into practice, which is not exercised yet in most transition countries. Main concern of foreign debt management should be gaining benefit from foreign finances, providing macroeconomic stability and maintain payment consumption. To achieve this state should well consider the relationship among investments, economic growth and foreign loans. However, appropriate legislative and methodological documentation should be created for managing domestic debts.

State should pay attention to the process of shifting to open economy, the directions of foreign economic policy, and studies the influence of foreign investments on economic growth, the problems of regulating exchange rate. One of the objectives of state transition economy is to make favorable conditions for national economic integration into world economics, international economic unions and organizations. Consequently, the country will be able to participate in international labor distribution processes resulting in efficient growth of national economics.

Reforms also require the introduction of national and foreign currency convertibility, amendment or elimination of tariff barriers, and reduction of tariffs, and liberalization of investment laws. The success of the above-mentioned reforms depends on the government's 
willingness to foster international trade and capital participation on international markets. International trade facilitates the adjustment of reasonable prices, expansion of market and makes available foreign technical and technological achievement for firms and individuals.

To facilitate domestic demand limitations government should change national currency course. The introduction of more devaluated course can lead to the decrease of demand on imported goods and increase competitiveness of exporting goods. The devaluation of currency should be pursued at the first stage of reforms. Although, inflation expected at this stage due to uncontrollable prices can easily defeat competitiveness achieved through devaluations. Devaluations can also hamper credit availability and reduce money supply, thus supporting strict monetary - fiscal policy.

Together with the establishment of currency course, it's important to provide convertibility of currency for economic openness, world price impacts and usage of international competition

benefits. Besides, currency convertibility promotes transnational corporations to provide transition countries with modern technologies, knowledge management and business and expand trade relations with them. The transnational corporations' interest in transition countries is owing to the following: Low price of working force; guarantee their beneficial position at a potential market.

Although the majority of governments of transition countries support the direct inflow of foreign investments, western firms don't hurry to invest capital in them due to inconvertibility of their currencies, political instability and the absence of appropriate financial structure.

The reason of foreign investment hamper in countries under transition is: Absence of legislation defending the interests of transnational corporations; heavy and time consuming bureaucratic system; destroyed infrastructure; low work productivity owing to low value of labor power.

It's important to gain foreign financial aid for transition countries to provide currency reserves, create infrastructure and stabilize economics. In Eastern European Countries and the CIS countries foreign financial assistance is used to facilitate economic stabilization, balance taxation, create new infrastructure, establish new companies and improve firms' productive base.

Finally, because the optimal role for government derives not just from economic considerations but also from the interplay of political and economic forces, the views of the 
executive branch of government should broadly match those of the legislative branch. If the two sides are miles apart on what the government should do, as they have been in Russia and some other countries, neither an optimal government role nor rational policies are likely to emerge.

\section{Conclusion}

The transition, with its classical definition, aims that the market, itself, is the central mechanism of resource allocation. In transition we should avoid, what Galbraith calls "simplistic ideology ${ }^{31 ",}$ what Przeworski calls "neoliberal fallacy ${ }^{32 ",}$ or what Kornai calls "uncritical, mythical cult of the market ${ }^{33}$. The market is not a panacea for solving all our socioeconomic problems. Nor is it a neutral, natural, apolitical, and ahistorical institution. Moreover, the market is not an end in itself. Rather, it is just a means to promote social and individual welfare. For this reason, the potential role of non-market means, including state intervention, in improving welfare should be neither dismissed nor underestimated.

Any governments intervention in the life of market is caused by default or design. In modern world, less government intervention doesn't produce welfare for people. This happens in those countries, where played a huge role in the structural adjustment on economic, where international competitiveness were much more stronger, economic growth were more sustained and distribution of income and wealth were equal ${ }^{34}$.

In recent period, despite the influence of neoliberal ideas, the state's main directed strategy is the only effective way to undertake economic transition or economic development. Yet it appears that the latter type of strategy, despite its effectiveness when it is carried out, tends to be self-undermining Wealthy and powerful social actors will eventually push for a shift to a neoliberal strategy. They are aided in this objective by the influence of neoliberal ideology.

At the general level, economic policy, chosen by government seems to the most important for achieving sustainable growth at a transition period. This include a stable

\footnotetext{
${ }^{31}$ Galbraith, John K. 1990. "Revolt in Our Time: The Triumph of Simplistic Ideology,"

32 Przeworski, Adam. 1991. Democracy and the Market: Political and Economic Reforms in Eastern Europe and Latin America, (Cambridge University Press).

${ }^{33}$ Kornai, Janos. 1992. "The Post Socialist Transition and the State: Reflection in the Light of Hungarian Fiscal Problems," American Economic Review, vol. 82, no. 2.

${ }^{34}$ Katzenstein, Peter, ed. 1978. Between Power and Plenty (Madison: The University of Wisconsin Press; Johnson, Chalmers. 1982. MITI and the Japanese Miracle: The Growth of Industrial Policy, 1925-1975 (Stanford: Stanford University Press
} 
macroeconomic environment, generalized access to the world economy, protection of property rights, spending in public goods that provide benefit to all. Crucial question is why don't government pursue these sound policies. The lack of knowledge may be the part of the answer. Sound economic principles do not translate precisely into unique policy packages, but need to be adapted to the specific economic and social realities.

Lack of incentives seems to be much more important. What should be done to give the right incentives government of developing countries, short of waiting until they become mature democracies? A practical answer of this is that there are beneficial complementarities from political and economic liberalization. Political liberalization facilitates opening up the economy to international competition, probably because democracy increases the political influence of those that are more likely to benefit from international integration. But economic liberalization seems a necessary step towards economic success: without it, new democracies do not prosper.

\section{Academic Biography}

Giorgi Kharshiladze, Doctor of economics, born in Tbilisi, Georgia on January 11, 1983. In 1989-2000 studied 53 ${ }^{\text {rd }}$ public school. In 2000-2006 studied in Caucasus Business School (Caucasus University) and got a bachelor degree in business administration (specialty Marketing). In 2009-2011 studied economics in Saint Andrew the First Called Georgian University and in 2011 got a master's degree in economics (master's thesis was "state property in Georgia") and in 2015 got Doctor's degree in Economics in Saint Andrew the First Called Georgian University (Doctoral thesis "structural changes in Geogian economy in transition period"). Participated in many international or local conferences and published 12 scientific articles and 1 monography. From March, 2019 is invited specialist (professor) of Georgian National University (SEU). Sphere of interests are transition period, transition countries, transition economies, macroeconomic stabilization, International trade and international relations.

\section{Bibliography}

1. Arndt, Heinz W. 1988. "'Market Failure' and Underdevelopment." World Development, vol. 16 , no. 2 
2. Aristovnik, Aleksander (19 July, 2006) - "The determinants \& Excessiveness of current account deficits in Eastern Europe and the Former Soviet Union." William Davidson Institute, University of Michigan

3. Alan Smith, Introduction in Alan Smith (editor), Challenges for Russian Economic Reform, 1995, London: Royal Institute for International Affairs and Washington DC: The Brookings Institution

4. Garnaut, Ross. 1991. "The Market and the State in Economic Development: Applications to the International Trading System," The Singapore Economic Review, vol. 26 , no. 2

5. EBRD's 1994 Transition Report

6. EBRD, Transition Report 2013, London: European Bank for Reconstruction and Development

7. EBRD, Transition Report 2000, London: European Bank for Reconstruction and Development,

8. EBRD, Transition Report 2008, London: European Bank for Reconstruction and Development,

9. EBRD, Transition Report 2010, London: European Bank for Reconstruction and Development,

10. Galbraith, John K. 1990. "Revolt in Our Time: The Triumph of Simplistic Ideology,"

11. Katzenstein, Peter, ed. 1978. Between Power and Plenty (Madison: The University of Wisconsin Press; Johnson, Chalmers. 1982. MITI and the Japanese Miracle: The Growth of Industrial Policy, 1925-1975 (Stanford: Stanford University Press

12. László Csaba, Transformation as a subject of economic theory in Zbyněk Balandrán and Vít Havránek, Atlas of Transformation, 2011, retrieved 1/11/2013; Jeffrey Sachs, What I did in Russia, posted 14 March 2012, retrieved 1/11/2013.

13. Michael Kaser on Privatization in the CIS in Alan Smith (editor), Challenges for Russian Economic Reform, 1995, London: Royal Institute for International Affairs and Washington DC: The Brookings Institution,

14. Havrylyshyn, Oleh; Wolf, Thomas. (1999). "Determinants of Growth in Transition Countries, Finance \& Development Magazine, June 1999, Volume 36, Number 2 by the International Monetary Fund 
15. Marie Lavigne, The Economies of Transition: From socialist economy to market economy, 1995, London: Macmillan

16. Marie Lavigne, The Economies of Transition: From socialist economy to market economy, 1995, London: Macmillan, pp.

17. MF staff estimates in Stanley Fischer, Ratna Sahay and Carlos Vegh, Stabilization and growth in transition economies: The early experience, April 1996, IMF Working Paper WP/96/31; downloaded from http://mpra.ub.uni-muenchen.de/20631/; retrieved on 1/11.2013; UNDP, Human Development Report for Central and Eastern Europe and the CIS, 1999, New York: United Nations Development Programme,

18. IMF. (2000). "Transition Economies: An IMF Perspective and Progress and Prospects". IMF. 3 November 2000. Retrieved 9 March 2009.

19. Napier, Nancy K., Vuong Quan-Hoang. (2013). What we see, why we worry, why we hope: Vietnam going forward. Boise, ID: Boise State University CCI Presss, October 2013

20. Przeworski, Adam. 1991. Democracy and the Market: Political and Economic Reforms in Eastern Europe and Latin America, (Cambridge University Press).

21. Kornai, Janos. 1992. "The Post Socialist Transition and the State: Reflection in the Light of Hungarian Fiscal Problems," American Economic Review, vol. 82, no. 2.

22. The first ten years: Analysis and Lessons for Eastern Europe and the Former Soviet Union" (PDF). The International Bank for Reconstruction and Development/The World Bank 2002 Retrieved 9 March 2009

23. Vuong, Quan-Hoang. (2010). Financial Markets in Vietnam's Transition Economy: Facts, insights, implication. Saarbrücken, Germany: VDM Verlag Feb. 2010

24. Simon Clarke (editor), Structural Adjustment without Mass Unemployment? Lessons from Russia, 1998, Cheltenham: Edward Elgar, J L Porket, Unemployment in Capitalist, Communist and Post-Communist Economies, 1995, London: Macmillan

25. Thompson, E. P. 1971. "The Moral Economy of the English Crowd in the Eighteenth Century," Past and Present, no. 50.

26. The UNDP used a poverty line of $\$ 4$ per person per day in 1990 dollars at purchasing power parity; UNDP, Human Development Report for Central and Eastern Europe and the CIS, 1999, New York: United Nations Development Programme, 